\title{
The Need and Methods for the State Regulation of Private Medical Services in the Conditions of the COVID-19 Pandemic
}

Section: Healthcare

Sci. Journal Impact

Factor: 6.1 (2018)

ICV: 90.90 (2018)

\section{Rajabov Utkir Dusnaevich}

Associate Professor of Tourism and Hotel Management, Termez State University, Uzbekistan.

Copyright@IJCRR

\section{ABSTRACT}

Background: The article recognizes the need for state regulation of the market of medical services and its features, the need to distinguish it from other markets, the conditions created in Uzbekistan in its development, the composition of the social market and the caution in introducing market relations, the possibility of contacting people of different ages and different categories, especially in conditions of the coronavirus pandemic.

Aim: To develop conditions for the nationwide development of the level of provision of private medical services in the conditions of a pandemic and to research methods of state regulation of the provision of private medical services.

Objective: Determination of the need for private medical services and state regulation in the event of a pandemic.

Results: The article emphasizes the expediency to maintain the partial smoothness of these services, taking into account the fact that the introduction of market laws in the provision of medical services and the provision of paid services as a whole can lead to dangerous consequences and cause social problems, adding a system of paid infertility. In the introduction of market legislation to medical services, the expediency of employment of the population to be studied in such aspects as their monetary income and cultural level how positive these aspects are will be brought about in such a way that it will reduce the negative impact of the medical services market practice to such an extent. The state avoids the problems between workers and subjects in the social sphere. All this is explained by the emergence of methods of harmonization of the social sphere and states with the market mechanism of regulating its development in a single framework.

Conclusion: In the conclusion of the scientific work, in the current conditions in which the coronavirus pandemic is widespread, proposals have been made on alternative methods and directions of the emergence and regulation of the population as the main reformer of the state in the equal use of special medical services among state medical institutions. The reforms carried out in Uzbekistan in health care and their social orientation, equality in the use of medical services have been preserved, and necessary proposals have been made to regulate private medical services by the state.

Key Words: Private medical services, Features, Conflicts, Social aspects, State regulation, Responsibility

\section{INTRODUCTION}

Human is a Biosocial creature not to be reckoned with by its biological aspects, it is nonsense to ignore the fact that people are in a state of health, their physical needs and ability to work, many other natural-scientific features of human. Therefore, it is recognized that the organization of the private sector in the provision of medical services to the population and the introduction of market relations should take into account social aspects, be cautious and regulated by the state. ${ }^{1-3}$ In the decision-making and development of the market relationship in the provision of medical services, it is neces- sary to have a deeper understanding and analysis of the market mechanism, movement, capacities, characteristics. The medical services market is significantly different from other types of markets by its significant characteristics. ${ }^{4-6}$

Until now, many foreign and domestic scientists have shown interest in the theoretical foundations of the provision of medical services and topical issues of development of the private sector. In their research, they proved that the problem of organizing and developing the market for medical services is complex and universal. A group of reserachers and policy makers in Uzbekistan, focused on the role

\section{Corresponding Author:}

Rajabov Utkir Dusnaevich, Associate Professor of Tourism and Hotel Management, Termez State University, Uzbekistan. Email: udrajabov@mail.ru

ISSN: 2231-2196 (Print)

Received: 18.08 .2020
ISSN: 0975-5241 (Online)

Revised: 20.09 .2020
Accepted: 08.10 .2020 
and directions of the private sector in public health. ${ }^{7,8}$ In most of these studies, priority was given to the study of the universal aspects of private medicine. However, the mechanism and social aspects of the medical services market validity and capacities in the conditions of the coronavirus pandemic have not been studied to a large extent. The medical services market is a component of a socially-oriented market that covers a wide segment of the population, indifference to which can lead to contradictory consequences in the development of society.

In the provision of medical services, it is not difficult to imagine how dangerous the introduction of market legislation in full and the provision of equally paid services to all will be. Taking into account the dangerous and dangerous effects of this situation, in many developed countries, the partial smoothness of these services has been preserved and is carried out with the addition of a paid, infertility system. ${ }^{8,9}$ In the introduction of market legislation for medical services, it is worthwhile to study aspects of employment of the population, such as their monetary income and cultural level. How positive these aspects are will ensure the stability of the medical services market in operation.

It is also not without reason that the subjects of medical services are protected by the state in the conditions of socially oriented market relations. The transition to market relations requires an analysis of medical services one by one. The trends in the development of the healthcare system testify to the growing importance and role of the medical business in many countries around the world. International experiments show that medicine without the private sector can not provide a wide layer of the population with quality services. Nevertheless, budget expenditure allocated to health care in developed countries is growing. Health care after the National defence costs is 6-7 per cent of the budget expenditure. $^{9}$

\section{MATERIALS AND METHODS}

Uzbekistan has chosen a socially-oriented evolutionary pathway of transition to market relations. This principle is also seen in the processes of establishing the medical services market in the healthcare sector.

Article 40 of the Constitution of the Republic of Uzbekistan establishes the right of each person to use qualified medical services. ${ }^{10}$ The pandemic of COVID-19, which worries the world population, is gaining equal access to free medical services of all strata of the population, while remaining faithful to this principle, even in the most widespread current conditions. In a short time, to mitigate the effects of the
COVID-19 pandemic, additional hospitals have been built in all regions, making them ready to provide medical services to patients.

Social relations in Uzbekistan, which has been dominated by the values of kindness and humanity since previous times, are evident in achieving social stability with the development of the market economy, in the role and importance of the population in the use of medical services in the conditions of the COVID-19 pandemic.

In the conditions of structural changes taking place in the economy, on the one hand, in the general structure of the population, there is an increase in the salinity of the part of the population that has a high income due to its practicality and entrepreneurship, the fact that both for quality prophylactic medical services and the possibility of its acquisition also have a growing trend, on the second hand, the need to avoid losses during the transition period and the need for social protection of those in need, imposes more complex tasks in the provision of medical services.

The specific aspect or community of the health care system is that its problems affect the entire population. Everyone appeals to medical institutions for help at this or that level, regardless of their age, gender, level of knowledge and social status. Its worthiness to work, the relationship in the family, the level of trust in public policy in the field of health, depends on the quality of this assistance. ${ }^{11}$

In the healthcare industry, several specific factors limit the high level of market principles and hinder the introduction of market relations, which can lead to socio - negative consequences of ignoring them. These can include the following;

- the fact that medical services are is a social commodity;

- the fact that medical services are in the interest of not only an individual but also the whole society;

- the presence of a print of equity in the receipt of medical care;

- an unevenness of population location;

- the conflict of sale of all types of medical services for money in the interests of human;

- the possibility of creating socio-economic risks to society;

- features associated with inequality and solvency of incomes of the population.

In the process of structural changes carried out in Uzbekistan with the aim of liberalization of economic reforms and expansion of market relations, the increase of private medical institutions on the account of domestic and foreign investments is supported (Table 1). 
Table 1: The trend of growth in the number of private medical institutions from year by year

\begin{tabular}{|c|c|c|c|c|c|c|c|c|c|c|c|}
\hline Years & $\begin{array}{l}\text { The } \\
2008 \\
\text { year }\end{array}$ & $\begin{array}{l}\text { The } \\
2009 \\
\text { year }\end{array}$ & $\begin{array}{l}\text { The } \\
2010 \\
\text { year }\end{array}$ & $\begin{array}{l}\text { The } \\
2011 \\
\text { year }\end{array}$ & $\begin{array}{l}\text { The } \\
2012 \\
\text { year }\end{array}$ & $\begin{array}{l}\text { The } \\
2013 \\
\text { year }\end{array}$ & $\begin{array}{l}\text { The } \\
2014 \\
\text { year }\end{array}$ & $\begin{array}{l}\text { The } \\
2015 \\
\text { year }\end{array}$ & $\begin{array}{l}\text { The } \\
2016 \\
\text { year }\end{array}$ & $\begin{array}{l}\text { The } \\
2017 \\
\text { year }\end{array}$ & $\begin{array}{l}\text { The } \\
2018 \\
\text { year }\end{array}$ \\
\hline $\begin{array}{l}\text { Number of private medical } \\
\text { institutions }\end{array}$ & 237 & 280 & 325 & 361 & 414 & 382 & 375 & 406 & 447 & 493 & 529 \\
\hline $\begin{array}{l}\text { The number of doctors in } \\
\text { them (a thousand human) }\end{array}$ & & & & & 18117 & 19052 & 23409 & 25281 & 27258 & 31437 & 33179 \\
\hline $\begin{array}{l}\text { Number of hospital facili- } \\
\text { ties to the state }\end{array}$ & 1139 & 1162 & 1158 & 1181 & 1225 & 1128 & 1058 & 1071 & 1106 & 1135 & 1165 \\
\hline $\begin{array}{l}\text { Number of doctors in all } \\
\text { specialities (a thousand } \\
\text { human) }\end{array}$ & 77,1 & 80,4 & 79,9 & 81,7 & 81,3 & 81,7 & 82 & 83,4 & 84,1 & 85,4 & 89,8 \\
\hline
\end{tabular}

\section{RESULTS AND DISCUSSION}

At the same time, in the conditions of the COVID-19 pandemic, the participation of private medical institutions in the restoration of Public Health was achieved state regulation. Among the state medical institutions, private medical institutions were also responsible for providing medical services to the population. On March 15, 2020, in the Republic of Uzbekistan, since the first time the COVID-19 pandemic has been identified, priority has always been given to the abovementioned characteristics, limiting the high level of market principles in maintaining the health of the population. As its confirmation, the decision of the president of the Republic of Uzbekistan "On additional measures to prevent the spread of COVID-19 infection in the Republic of Uzbekistan" on March 26, 2020, PD-4649 was put into practice. ${ }^{12}$

To prevent the spread of COVID-19 infection, to ensure the sanitary and epidemiological peace of the population, as well as to restore the health of patients, state medical institutions and non-governmental medical organizations have been instructed. According to this decision:

- Non-profit medical organizations are allowed to provide medical services to patients with COVID-19 infection, which are included in the range of infectious diseases requiring urgent prophylaxis and anti-epidemic measures, until 1 September 2020, the specified period can be changed by the Republican special commission for the preparation of the program of measures to prevent the penetration and spread of COVID-19 into the Republic of Uzbekistan

- Approval of the proposals of non-governmental medical organizations on the implementation of medical services for patients with COVID-19 infection only by the agreements concluded between the Ministry of the health of the Republic of Uzbekistan and non-governmental medical organizations;

- Reimbursement of expenses of non-state medical organizations related to the provision of medical services to patients with COVID-19 infection from the account of funds of the Fund for the fight against the crisis under the Ministry of Finance of the Republic of Uzbekistan;

- Use of laboratory-diagnostic services in coordination with non-governmental medical organizations in the detection of COVID-19 infection by the decision of the special commission, if necessary, arising from the epidemiological situation;

- Non-profit medical organizations train medical personnel with practical skills to prevent the spread of COVID-19 infection and apply modern and effective methods of its treatment;

- To propose the special commission on the use of laboratory-diagnostic services of non-state medical organizations in connection with the epidemiological situation associated with the spread of COVID-19 infection;

- Maintaining a strict account of the results of the placement and treatment of patients in non-governmental medical organizations;

- To ensure that service personnel of non-state medical organizations operate in strict compliance with the requirements of personal hygiene;

- To ensure systematic processing of non-governmental medical organizations ' buildings and structures using disinfection;

- It was determined that measures should be taken to create a sufficient reserve of means of disinfection for the full implementation of disinfection measures.

Within the framework of this procedure, private clinics, which are subjects of the medical services market, conclude agreements with the Ministry of Health. The ministry identifies private entities that treat patients with COVID-19 infection, with the exception, without making a choice. The office also carried out control over the provision of clinical practice by them, including the training of medical personnel with the necessary practical skills, the strict adherence of the service personnel to the requirements of personal hygiene, the provision of means of disinfection and the observance of arbitrations at the appropriate level. Due to the epidemiological 
situation, laboratory-diagnostic services of private medical organizations are used in the detection of COVID-19 infection in case of necessity. The decision of the special commission will be the basis for this, and also it will be required to agree with the clinic itself.

It is clear that during the COVID-19 pandemic, the need for citizens to purchase medicines for protection from viruses and infections, immunization and treatment will increase. As a logical continuation of the above work, it was adopted to take the necessary measures in such a situation to prevent the occurrence of artificial insufficiency of medical preparations with increased demand for the population and increasing the price, as well as to protect the life and health of citizens and to provide timely medical assistance to patients, By the resolution of the Cabinet of Ministers of the Republic of Uzbekistan "On measures to regulate the circulation of medicines, medical products and medical equipment during the COVID-19 pandemic period" dated July 22, 2020, 449, by the resolution of the Cabinet of Ministers dated August 11, 2020 , No. $474^{13}$, the drugs used in the treatment of patients, the temporary suspension of medical products and medical equipment outside the territory of the Republic of Uzbekistan (except the reexport customs regime) until October 1, 2020, has been established.

To create additional conditions for the rapid development of the private sector in the field of health care, the provision of ambulance services to the population by non-governmental medical organizations, On May 30, 2020, the president of the Republic of Uzbekistan" on the creation of additional conditions for the provision of ambulance services by nongovernmental medical organizations, In the decision of PP4737, it was determined that non-resident medical organizations will exempt import customs duty for the period up to 1 January 2022 for new ambulance cars imported into the territory of the Republic for their own needs. ${ }^{14}$ Entering the market economy with medical services is more difficult than entering with goods. In the era of these services, the interests of Man and the whole society will remain the future generation. Given the fact that there is a disparity between the segments involved in the medical services market-the population of different strata, it is obvious that the medical services market can not even protect their interests. ${ }^{15}$ That is why it is necessary to actively intervene in the regulation of the state medical services market. One of the generally recognized disadvantages of a market economy is that it is not capable of generating socially desirable favours and services and offering them to the market. It is for this reason that the provision of such blessings and services to members of the society is under the responsibility of the state.

The state should be the main concentrating force in the management of the market, in the provision of benefits to some tribes of the population, in the specification and regulation of paid service lines. ${ }^{17}$ No matter how many advantages the market economy has, it is difficult to ensure social stability. Therefore, the state will come out as a harbinger of problems between workers and subjects in the social sphere. All this suggests that for the social sphere and its smooth development it is necessary to harmonize the state with the market mechanism of regulation. ${ }^{1}$

\section{CONCLUSION}

The view of human health as the most important socio-economic issue is one of the important factors that ensure the development of society and the development of the country. Only a healthy person can actively participate in all aspects of society's life. Therefore, in the current conditions in which the COVID-19 pandemic is spreading widely, the state should take up the field as the chief reformer and use alternative methods of regulation in the equal use of private medical services among state medical institutions.

In my opinion, among them it is possible to add the following lines:

- the application of tax benefits for medical services rendered freely by private medical institutions to the population;

- to encourage private medical institutions, which have taken a special initiative in the fight against disease in the conditions of the pandemic, by informing the general public;

- to determine the need to provide free services to the population in case of emergency in the licensing of private medical institutions;

- setting the upper limit of prices for medical services, equipment and medicines in the conditions of the pandemic

\section{ACKNOWLEDGMENT}

Authors acknowledge the immense help received from the scholars whose articles are cited and included in references to this manuscript. The authors are also grateful to authors / editors / publishers of all those articles, journals, and books from which the literature for this article has been reviewed and discussed.

\section{Conflict of Interest: Nil}

Funding. Through the state reimbursement of costs for medical services rendered for the pandemic and the state reimbursement of salaries of medical personnel, it will be possible to mitigate the market of medical services and adapt to the population in the conditions of the pandemic time. 


\section{REFERENCES}

1. Sheyanov D. Formation and development of the market for paid medical services [Abstract of dissertation for the degree of candidate of economic sciences]; 2013; 22-23.

2. Kolobukhov P. Modern approaches to providing medical care in the private health care system (on the example of the Kaliningrad region) [Abstract of dissertation for the degree of candidate of economic sciences]. St. Petersburg; 2020; 20-21.

3. Vasilieva O. Current state and mechanisms of modernization of the Russian market of medical services [Abstract of the thesis for the degree of candidate of economic sciences]. St. Petersburg; 2013; 5:22-24.

4. Krestyaninova O. Development of the market of medical services in the context of informatization of society [Abstract of dissertation for the degree of candidate of economic sciences]. St. Petersburg; 2019; 3:21-22.

5. Polyanskaya E. Transformation of the market of medical services (on the example of the Amur region) [Doctoral dissertation]. Pacific State University, Khabarovsk; 2010; 4:22-23.

6. Rahmonov D. Improving the methodological framework for financing the social sphere in Uzbekistan [Abstract of the dissertation for the degree of Doctor of Economics]. Tashkent; 2018; 5:72-75.

7. Ziyaeva M. Marketing strategy for the development of the services market [Abstract of the dissertation for the degree of Doctor of Economics]. Tashkent State University of Economics; 2018; 6:67-68.

8. Alieva G. Improving the management of social infrastructure development [Abstract of the dissertation for the degree of Doc- tor of Philosophy $(\mathrm{PhD})$ in Economics]. Tashkent State University of Economics; 2020; 56.

9. Galkin V. Medical business. 3rd ed. Moscow: KNORUS; 2007; 7-11.

10. The Supreme Council of the Republic of Uzbekistan. Constitution of the Republic of Uzbekistan. Tashkent: Ozbekiston; 1992; 16.

11. Ziyaev T, Isroilova S, Yokubov D. Economy of the social sphere. Tashkent State Economic University. 2011;35.

12. President of the Republic of Uzbekistan. Resolution PQ-4649 on additional measures to prevent the spread of coronavirus infection in the Republic of Uzbekistan. Tashkent: Uzbekistan; 2020.

13. Cabinet of Ministers of the Republic of Uzbekistan. Resolution No. 474 of July 22, 2020 "On measures to regulate the circulation of medicines, medical products and medical equipment during the coronavirus pandemic". Tashkent: Uzbekistan; 2020.

14. President of the Republic of Uzbekistan. Decree PQ-4737 on the creation of additional conditions for the provision of emergency medical care by non-governmental medical organizations. Tashkent: Uzbekistan; 2020.

15. Abulkosimov H. State regulation of the economy. Noshirlik yogdusi. 2018; 6: 212.

16. Shodmonov S.S., Gofurov U.V. Theory of Economics. Economics- Finance. 2010; 4:148.

17. Sultanovich, A. A., Ugli, M. M. D. Methods of forecasting and management of land fund diversification in local areas. Int J Rec Tech Eng 2019; 8(3); 403-411. 